\title{
Profile of Economic Units on the Manufacturing Sector: An Approach in the Case of Mexico
}

\author{
Arturo Córdova-Rangel ${ }^{*}$ \\ Research Professor of Graduate Studies and Research, Universidad Politécnica de Aguascalientes \\ Email: arturo.cordova@upa.edu.mx \\ Arturo García-Santillán \\ Researcher Professor at Administrative-Economic Research Center, Universidad Cristóbal Colón \\ Email: arturogarciasantillan@yahoo.com.mx \\ José G. Vargas-Hernández \\ Research Professor at the University Center for Economic and Managerial Sciences, Universidad de Guadalajara \\ Email: josevargas@cucea.udg.mx

\section{Ma. de Lourdes Y. Margain Fuentes} \\ Research Professor of Graduate Studies and Research, Universidad Politécnica de Aguascalientes \\ Email: lourdes.margain@upa.edu.mx

\section{Lourdes Isabel Ávila} \\ Master student, Universidad Politécnica de Aguascalientes \\ Email: lourdes.avila@upa.edu.mx
}

Doi:10.5901/mjss.2015.v6n4p21

\section{Abstract}

The aim of the study was to identify factors which describe the profile of economic units (EUs) in Mexico. For this purpose, were consulted the databases of the Ministry of Labor and Social Welfare (MLSW, "Secretaría del trabajo y Previsión Social" STPS, Mexico) and the National Institute of Statistic, Geography and Informatics (NISGI, "Instituto Nacional de Estadística, Geografía e Informática" - INEGI, Mexico), as institutions responsible for carry out officially, the application of surveys through the National Survey on Employment, Wages, Technology and Training in the manufacturing sector (NSEWTT, "Encuesta Nacional de Empleo, Salarios, Tecnología y Capacitación" - ENESTYC, Mexico). With the capture of these surveys by the institutions responsible, subsequently allow us determine the factors which describe the profile of the economic units. With this research we identified eight factors, which describe the profile of the economic units, being these: Establishment's characteristics (F1), Production and organization (F2), Market (F4), Quality control and technology (F5), Employment Forms (F6), Salaries (F7), Training and Health and safety (F8).

Keywords: Evaluation Factors, Economic units, Profile of EUs (Economic Units), Enterprise characteristics.

\section{Introduction}

The National Development Plan 2007-2012 (NDP, "Plan Nacional de Desarrollo" - PND, Mexico) de establishes as a strategy for development in Mexico of economic units, the following guiding principles: 1. Rule of law and security. 2. Competitive, job-creating economy. 3. Equality of opportunity. 4. Greening. 5. Effective democracy and responsible foreign policy. Under this strategy, the basic premise Plan, the pursuit of sustainable human development and a dignified life, i.e., a better quality of life for all Mexicans.

The focus of the economy and competitiveness that generates employment strategy includes a focus on three areas: investment in physical capital, capabilities of people and high productivity growth. The aim is to achieve faster and sustained growth that will generate more formal employment to improve the quality of life of Mexicans. Improve living 
conditions and opportunities for all, especially those living in poverty are a social imperative. The lack of financial resources and marginalization, preventing basic needs and limit the full participation of citizens in the fields: political, social, economic and cultural, as no employment opportunities and full participation in the economic progress of the country it is not possible to achieve integral human development.

It is clear that job creation brings stability, public safety and social interaction respectful of the rights of others. At the same time, economic growth must be without sacrificing natural resources, respecting the environment without compromising the welfare of future generations, are part of the purposes that holds the master plan (PND, 2007-2012).

Meanwhile, the Secretariat of Labor and Social Welfare ("STPS") and the National Institute of Statistics, Geography and Informatics ("INEGI"), initiated in 1992 lifting the National Survey of Employment, Wages, Technology and Training Sector, manufacturing ("ENESTYC"), in order to have information on: employment and training, work organization, production and technological aspects, all this, to analyze the profile of manufacturing sector in Mexico.

Also, it is important to emphasize that, with the analysis of this information; we would have a closer reality, allowing design proposals to help increase productivity in this sector. However, we must not forget that this has been a challenge for the Mexican manufacturing industry and in general for any sector of the national economy, which today are facing globalization.

Globalization brings innovation in production processes, as new technologies are introduced and the system is adopted in time, in addition to management systems for quality, as well as training of workers and changes in the organization of work through job rotation and employee participation in setting performance standards on issues that directly affect employment.

With the inclusion of technological innovation and their close relationship with quality systems and management quality (QM) it has a serious connotation to the theory of management and organization, highlighting the work of Cole and Scott (2000). Besides literature has been postulated to address quality in a serious relationship to the competitive position of the organization, as it would in this case the manufacturing sector, highlighting the work of Grant, Shani and Krishnan (1994); Powell (1995); Reed, Lemark and Montgomery (1996); Lee, Adam and Tuan (1999); Terziovski and Samson (1999) cited in Tena and Camai (2004).

In support of the above, and to register these changes in the organization of production in the National Survey of Employment, Wages, Technology and Training in the Manufacturing Sector ("ENESTYC") incorporates aspects that extend the information about surveys that have been conducted previously on: training, research and / or technological development and certification to international quality standards in production processes.

Additionally upon request of the World Bank were incorporated the "ENESTYC" questions that capture information on support programs and technical assistance to private and public institutions ("ENESTYC", 2001). In the same idea, comprehensive coverage "ENESTYC" manufacturing sector covers 54 branches established in the Mexican Classification of Activities and Products (MCAP, "Clasificación Mexicana de Actividades y Productos" - CMAP, Mexico, 1994). In "ENESTYC" is considered particularly important information to assess the behavior of this group of establishments (Profile), considering the global economic environment.

Besides this, just as methodological aspects that guide the development of the survey to capture data and proceed to process and with it to fulfill the main objective which is to satisfy the demand for information on specific topics are integrated, not only the Secretariat of Labor and Social Welfare ("STPS") but other public and research institutions, international organizations, researchers from national and international universities and business associations, among others.

Indicators which are measured by "ENESTYC": Characteristics of establishments, Production and organization, Market: main effects of the Free Trade Agreement (FTA, "Tratado de Libre Comercio" - TLC, Mexico), Quality control and technology, Forms of Employment, Remuneration, Training, Health and safety. In addition to the above, also includes information on the knowledge and industry participation in support programs offered by various public and private institutions ("ENESTYC", 2001).

Moreover, the Organization for Economic Cooperation and Development (OECD) Economies main indicators of the following factors (variables): Population Trends and Migration Macroeconomic Trends, Trends in Economic Globalization, Behavior of Prices, Behavior Energy Behavior of Employment, Science and Technology Trends, Environmental Trends, Trends in Education, Behavior of Public Finance, Quality of Life and finally Equity Income and Education.

With the arguments above and on the basis described in the National Development Plan 2007-2012, the National Survey of Employment, Wages, Technology and Training in the Manufacturing Sector "ENESTYC", and the Organization for the Cooperation and Development Economic (OECD), the following question arises: What are the factors that impact on the development of economic units? That is: What are the associated factors that favor the development of companies 


\section{in the manufacturing sector in Mexico?}

\subsection{Objectives}

Evaluate the associated factors that favor the development of the (business) economic units in the manufacturing sector in Mexico. And that according to described in the National Development Plan 2007-2012, and the "ENESTYC" and the OECD specifically seeks to study:

\subsubsection{Specific objectives}

- Identify the factors that favor the development of economic units.

- To prioritize the order in which they should address the factors that favor the development of economic units.

- To classify the variables and indicators that needs to be addressed to have a positive effect on the productivity of economic units.

- Design an alternative model of attention to the specific requirements of economic units in the manufacturing sector, based on the results obtained from the research.

\subsection{Hypothesis guides (empirical)}

We propose that the definition of an alternative model of support for economic units could help is given, more effectively and capitalization revival of manufacturing in Mexico. The model integrates indicators relating to: the characteristics of the establishments (age, tenure), production (organizational styles), market strategies, quality control and technology, styles or forms of employment, forms of remuneration, training programs, and health and safety systems.

Figure 1. Path Model Study

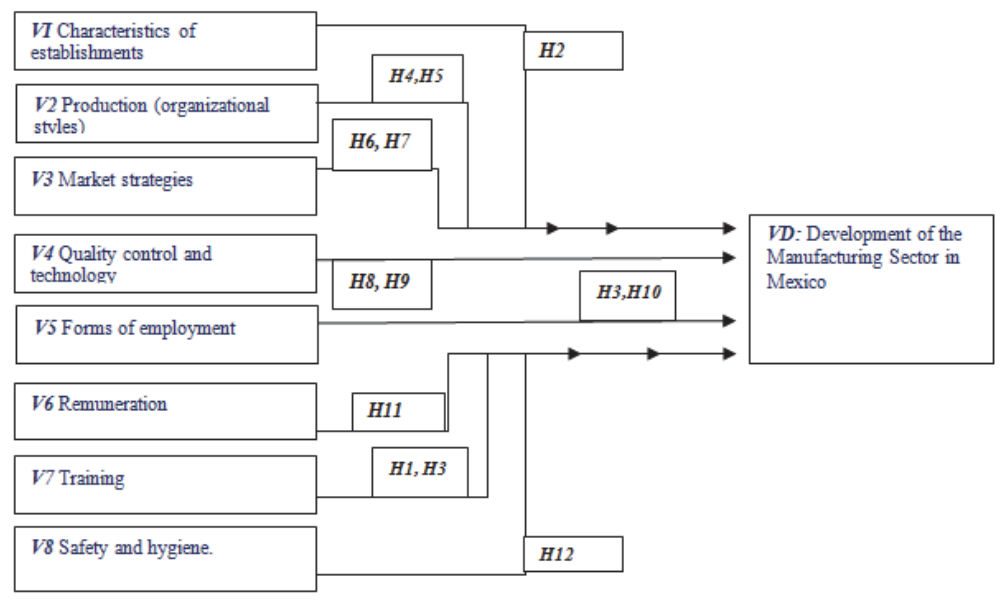

Source: (Own)

Since the previous model, the following hypotheses are posed (in the view of the executives surveyed):

H1: Staff training contributes the results of the EUs.

$\mathrm{H} 2$ : The permanence of EUs in the market favors the acquisition of experience to run the business.

H3: The level of education / formal and informal education of human capital that have the EUs, contributes to the development and success of businesses.

H4: The use of techniques and methods of quality control, favors the EUs to improve their production and operation.

H5: The use of techniques and methods of quality control, help in rates of Customer Satisfaction, Productivity Improvement and increase job satisfaction.

H6: The volume of sales and the percentage of internationalization is a significant indicator in the development and success of businesses. 
H7: The definition and operation of Public Policy help in sales volume and the rate of internationalization of firms and this in turn is an indicator of its development and success.

H8: The level of formal quality, in Quality with which count the UEs, contributes to the development and success of companies.

H9: The condition for research and / or technological of the EUs, contributes in its development and success.

H10: The EUs with a single worker without subsidiaries are less likely to develop than those that are comprised of more members and affiliates.

H11: The level of income received by members of the EUs favors their development and is indicative of its success.

H12: The condition of the EUs to form and operate health and safety committees, support the successful development of economic units.

\subsection{Methods and Procedures}

The research is of kind documentary. We review related studies to the purpose of the investigation. And it is a nonexperimental cross-sectional research, which begins as a descriptive to conclude as explanatory. During the first phase of data analysis is developed in a descriptive way and then, the statistical procedures were performed: the " $Z$ " proof of the assertion $\left(p=0, \mathrm{Ho}_{0} \neq 0\right)$ and then, we carry out the procedure Factorial Analysis of principal component extraction.

\subsubsection{Study population and informant}

The study population was Economic Units of the manufacturing sector in Aguascalientes, which are found registered with the Board of the Ministry of Economic Development. The number of UEs is 40 companies, thus we carry out a census, and to do this we send the questionnaire to all companies. Of total questionnaires sent, only 33 questionnaires were received. The information requested has been placed particular emphasis on the eight components which constitute variables involved in the phenomenon of study. The informants are the managers which have the responsibility within the enterprise, for making decisions

\subsubsection{Data Collection Instrument}

Starting from the National Development Plan (2007-2012) and the surveys carried out by "ENESTYC" and "OECD" a questionnaire which comprises 54 questions, was designed. This test is structured in the following way: 1) items Likert scale type; 2) open questions, and 3) closed and multiple choice questions (some dichotomous). Regarding the type of answers has the following classifications: 1) Numeric; 2) According to the Likert scale; 3) Multiple choices 4) Answers to open questions. In its thematic structure, the instrument collects data on the following variables of the model of study (figure 1).

\subsubsection{Data Capturing}

For each variable were collected numerical variables to can use the factorial analysis. An electronic spreadsheet was designed in the "Statistic v10.0" and SPSS v19.0 software to calculate the reliability level "Cronbach's Alpha" and the subsequent statistics tests.

\subsubsection{Statistical procedures (Z test of proportion)}

In the first place was carried out the proof of the assertion of proportion for testing the twelve (12) working hypothesis, which states that $p>0.5$ so their representation is: $H o: p=0.5, H i: p>0.5$ The procedure of asseveration about a population proportion $p(Z)$ is relevant if, differs from the assertion that $H o=0$ and the sampling distribution of sample proportions is approximated by a normal distribution (Triola, 2004).

Acceptance region is: Reject Ho: If $Z c>Z t$, otherwise not refuse. That is, if the value of the calculated $Z$ statistic is greater than the critical value of Tables is enough evidence for rejecting $\mathrm{Ho}$.

Another method used is Factorial Analysis to determine factor that have greater weight in the definition of the profile of the manufacturing sector. And that allows us to find starting from a set of variables, homogeneous groups to justify the model described in Figure 1. Subsequently the matrix of variance is calculated, which will be able to explain the 
variability of all variables, the extraction of the optimal number of factors, the rotation that facilitates its interpretation and the estimation of the scores of the subjects (economic units), on the new dimensions. The communalities are also obtained, which allow us to obtain the proportion of the variance of each the variables. In the percentages of explained variance, the eigenvalues of the variance-covariance matrix are shown, as well the variance percentages which representing each of one of them.

The model comprises twelve factors which were derived from the 8 variables (figure 1) in such a way that we can extract so many factors in the model, whenever they are greater than 1 for obtaining the percentage of explained variance of the model.

\section{Results}

\subsection{Validation of the Instrument}

To validate the questionnaire, we conducted a reliability test Cronbach's Alpha. This test allows validating the accuracy and consistency of the items (variables / indicators) of the instrument. From the result obtained, we can see that the standardized Cronbach's Alpha (hereinafter is identified as $a$ ) is slightly greater than $>0.5$ (table 1). From this, we may see that the instrument shows a standardized coefficient $a>0.5$, which indicates that the reliability of the items is acceptable and therefore the instrument has been validated (Hair, 1999 cited in García, 2004).

Table 1. Alpha Cronbach

\begin{tabular}{|c|c|c|c|c|c|}
\hline & Media if delete & Variance if delete & St. Dv. If delete & Items-Total Correlation & Alpha If delete \\
\hline $\mathrm{H} 2$ & 18.7576 & 22.5473 & 4.7484 & 0.1449 & 0.3883 \\
\hline $\mathrm{H} 10$ & 17.5455 & 19.0964 & 4.3699 & 0.0647 & 0.4530 \\
\hline $\mathrm{H} 4$ & 19.0000 & 21.4545 & 4.6319 & 0.3708 & 0.3456 \\
\hline H5 & 18.8788 & 20.5914 & 4.5378 & 0.3062 & 0.3392 \\
\hline H7_1 & 18.0000 & 18.6667 & 4.3205 & 0.4637 & 0.2758 \\
\hline $\mathrm{H} \overline{6}$ & 18.5455 & 23.2782 & 4.8248 & -0.0160 & 0.4318 \\
\hline H8 & 18.8182 & 22.6942 & 4.7638 & 0.0976 & 0.3985 \\
\hline $\mathrm{H} 9$ & 18.5455 & 20.9752 & 4.5799 & 0.1181 & 0.3965 \\
\hline $\mathrm{H} 3$ & 18.8182 & 21.1791 & 4.6021 & 0.3520 & 0.3421 \\
\hline $\mathrm{H} 11$ & 18.5152 & 21.8255 & 4.6718 & 0.1308 & 0.3897 \\
\hline $\mathrm{H} 1$ & 19.0000 & 22.0606 & 4.6969 & 0.3916 & 0.3572 \\
\hline $\mathrm{H} 12$ & 18.2424 & 22.0018 & 4.6906 & -0.0525 & 0.4915 \\
\hline
\end{tabular}

Source: (Own)

From the hypothesis test, the result of the $Z$ tests shown in Table 2

Table 2. Summary test $Z$

\begin{tabular}{ccccl}
\cline { 2 - 5 } Hypothesis & $p<0.05$ & $\hat{P}$ & Z & Decision \\
\hline H1 & 0.0005 & 0.78788 & 3.3074 & Is rejected Ho \\
H2 & 0.0594 & 0.63636 & 1.5666 & Is not rejected Ho \\
H3 & 0.0119 & 0.69697 & 2.2630 & Is rejected Ho \\
H4 & 0.0001 & 0.84848 & 4.0037 & Is rejected Ho \\
H5 & 0.0005 & 0.78788 & 3.3074 & Is rejected Ho \\
H6 & 0.1131 & 0.60606 & 1.2185 & Is not rejected Ho \\
H7 & 0.9955 & 0.27273 & 2.6111 & Is not rejected Ho \\
H8 & 0.0045 & 0.72727 & 2.6111 & Is rejected Ho \\
H9 & 0.0045 & 0.72727 & 2.6111 & Is rejected Ho \\
H10 & 0.9406 & 0.36364 & 1.5666 & Is not rejected Ho \\
H11 & 0.1922 & 0.57576 & 0.8703 & Is not rejected Ho \\
H12 & 0.1131 & 0.60606 & 1.2185 & Is not rejected Ho
\end{tabular}

Source: (Own) 
From the results shown in Table 2, can be seen that the variables that most affect industry development from the view of the respondents are:

V1: Staff training; V3: The level of education / formal and informal education of human capital; V4: The use of techniques and methods of quality control for the operation; V5: The use of techniques and methods of quality control as a means of Customer Satisfaction, Productivity Improvement and increase job satisfaction; V8: The level of formal quality Quality; V9: The condition for research and / or technological development.

And those that showed less evidence of incidence are the following variables:

V2: The permanence of economic units on the market; V6: The volume of sales and the percentage of internationalization; V7: The definition and operation of Public Policy; V10: Economic units with a single worker without subsidiaries; V11: The level of income received by members of the economic units; V12: The condition of the EUs to form and operate committees of health and safety.

To give greater strength to the test now we proceed to develop the measurement of data through the statistical procedure of Factorial Analysis with principal components extraction. Once again with the "Statistica" for Windows V.10.0 software, the following information is obtained.

Table 3. Analysis Correlation

\begin{tabular}{lcccccccccccc}
\hline & H2 & H10 & H4 & H5 & H7_1 & H6 & H8 & H9 & H3 & H11 & H1 & H12 \\
\hline H2 & 1 & 0.203 & 0.0076 & 0.0938 & 0.2323 & -0.2508 & -0.0393 & -0.0667 & 0.4524 & 0.0145 & 0.4223 & -0.1419 \\
H10 & 1 & 0.2448 & 0.3338 & 0.3343 & -0.0465 & -0.1267 & -0.0704 & -0.1607 & -0.1008 & -0.0179 & -0.1334 \\
H4 & & 1 & 0.9352 & 0.0026 & 0.2055 & 0.2047 & -0.1263 & 0.1008 & 0.1444 & 0.0996 & -0.0808 \\
H5 & & & 1 & 0.0027 & 0.2763 & 0.0747 & -0.1305 & 0.0825 & 0.0085 & 0.0706 & -0.1299 \\
H7.1 & & & & 1 & -0.1292 & -0.1516 & 0.2883 & 0.5952 & 0.0326 & 0.2889 & 0.2456 \\
H6 & & & & & 1 & 0.4539 & 0.1377 & -0.113 & -0.0512 & -0.2807 & -0.1935 \\
H8 & & & & & & 1 & 0.2889 & -0.0471 & 0.1745 & 0.1204 & -0.1936 \\
H9 & & & & & & & 1 & 0.1011 & 0.0061 & 0.0665 & 0.0803 \\
H3 & & & & & & & & 1 & 0.2329 & 0.7133 & 0.1426 \\
H11 & & & & & & & & & 1 & 0.4304 & 0.1031 \\
H1 & & & & & & & & & & 1 & 0.1423 \\
H12 & & & & & & & & & & & 1 \\
\hline
\end{tabular}

Source: (Own)

As we can see in Table 3, it is confirmed that the factors with higher correlation values are $\mathrm{H} 4$ with $\mathrm{H} 5$ (0.9352), $\mathrm{H} 7.1$ with $\mathrm{H} 3$ (0.5952), and HI with H3 (0.7133). In earlier tests, these same factors had already shown to be those with highest incidence in the model of study. Furthermore in table 4 show factors loadings.

Table 4. Factor Loadings Unrotated

\begin{tabular}{cccccc}
\hline \multicolumn{5}{c}{ Extraction: Principal components(Marked loadings are $>.700000)$} \\
\hline H2: & Factor 1 & Factor 2 & Factor 3 & Factor 4 & Factor 5 \\
H10 & -0.599 & -0.041 & 0.236 & 0.054 & 0.581 \\
H4 & -0.136 & -0.372 & 0.564 & -0.411 & 0.096 \\
H5 & -0.165 & -0.899 & 0.075 & 0.115 & -0.275 \\
H7_1 & -0.144 & -0.913 & 0.198 & 0.029 & -0.196 \\
H6 & -0.666 & 0.085 & 0.104 & -0.602 & -0.145 \\
H8 & 0.355 & -0.491 & -0.463 & -0.268 & 0.027 \\
H9 & 0.088 & -0.375 & -0.730 & -0.057 & 0.260 \\
H3 & -0.116 & 0.107 & -0.531 & -0.643 & -0.007 \\
H11 & -0.869 & 0.030 & -0.173 & -0.002 & 0.037 \\
H1 & -0.379 & -0.074 & -0.404 & 0.458 & -0.199 \\
H12 & -0.831 & -0.002 & -0.220 & 0.262 & 0.086 \\
Expl.Var & -0.243 & 0.338 & -0.035 & -0.058 & -0.766 \\
Prp.Totl & 2.664 & 2.302 & 1.702 & 1.318 & 1.185 \\
& 0.222 & 0.192 & 0.142 & 0.110 & 0.099 \\
\hline
\end{tabular}

Source: (Own) 
With the results shown in Table 4, we can identify factors loads $>0.7$ being these: Factor 1 : The level of education of human capital, The training of staff; Factor 2: The Use of techniques and methods of quality control and its impact on customer satisfaction indices, increased in productivity and job satisfaction; Factor 3: The quality level of economic units and Factor 5: Committees Health and Safety, and finally the Factor 4: without factor loadings $>0.7$

To maximize the sum of the variances, the Varimax method is used because it is a rotation method, which minimizes the number of variables with a high load factor, thereby improving the ability to interpret the factors. The new axes are obtained by maximizing the sum of $k$ factors withheld from the variety of the squared factor loadings within each factor. Subsequently, in order to avoid that variables with greater commonality, may have more weight in the final solution, the normalization Kaiser is performed. In table 5 and 6 are shown, those factor weights obtained with the varimax rotation and varimax normalized:

Table 5. Factor Loadings (Varimax raw)

\begin{tabular}{cccccc}
\hline \multicolumn{5}{c}{ Extraction: Principal components(Marked loadings are > .700000) } \\
& Factor 1 & Factor 2 & Factor 3 & Factor 4 & Factor 5 \\
\hline H2 & 0.5423 & -0.0020 & -0.2173 & 0.2109 & -0.6091 \\
H10 & -0.1923 & 0.4173 & -0.2614 & 0.5105 & -0.3351 \\
H4 & 0.0904 & 0.9542 & 0.0930 & -0.0411 & 0.0303 \\
H5 & 0.0147 & 0.9602 & 0.0325 & 0.0453 & -0.0811 \\
H7 1 & 0.3372 & 0.0191 & -0.0610 & 0.8441 & 0.1167 \\
H6 & -0.2944 & 0.2852 & 0.6960 & -0.0344 & -0.0295 \\
H8 & 0.1235 & 0.1046 & 0.8220 & -0.1737 & -0.1426 \\
H9 & 0.0365 & -0.2440 & 0.6130 & 0.5104 & 0.1544 \\
H3 & $\mathbf{0 . 8 2 2 7}$ & 0.0321 & 0.0050 & 0.3293 & 0.0239 \\
H11 & 0.5852 & 0.1244 & 0.1369 & -0.3176 & 0.2895 \\
H1 & $\mathbf{0 . 8 9 8 8}$ & 0.0543 & -0.0127 & 0.0672 & -0.0096 \\
H12 & 0.1370 & -0.0737 & -0.2140 & 0.2139 & $\mathbf{0 . 8 0 5 6}$ \\
Expl.Var & 2.4023 & 2.1835 & 1.7296 & 1.5729 & 1.2830 \\
Prp.Totl & 0.2002 & 0.1820 & 0.1441 & 0.1311 & 0.1069 \\
\hline
\end{tabular}

Source: (Own)

Table 6. Factor Loadings (Varimax raw normalized)

\begin{tabular}{cccccc}
\multicolumn{7}{c}{ Extraction: Principal components (Marked loadings are $>.700000)$} & \\
& Factor 1 & Factor 2 & Factor 3 & Factor 4 & Factor 5 \\
\hline H2 & 0.4144 & 0.0102 & 0.2327 & 0.2455 & 0.6860 \\
H10 & -0.2988 & 0.4575 & 0.2284 & 0.4457 & 0.3209 \\
H4 & 0.1381 & $\mathbf{0 . 9 4 2 3}$ & -0.1388 & -0.0500 & -0.0328 \\
H5 & 0.0351 & $\mathbf{0 . 9 5 8 1}$ & -0.0852 & 0.0189 & 0.0712 \\
H7_1 & 0.2301 & 0.0401 & 0.1106 & $\mathbf{0 . 8 8 0 1}$ & -0.0503 \\
H6 & -0.2361 & 0.2531 & -0.7285 & -0.0519 & -0.0338 \\
H8 & 0.1789 & 0.0514 & -0.8271 & -0.1308 & 0.1286 \\
H9 & 0.0148 & -0.2631 & -0.5733 & 0.5477 & -0.1513 \\
H3 & 0.7675 & 0.0200 & 0.0548 & 0.4313 & 0.0918 \\
H11 & 0.6651 & 0.0861 & -0.1056 & -0.2260 & -0.2222 \\
H1 & $\mathbf{0 . 8 7 2 5}$ & 0.0327 & 0.0667 & 0.1789 & 0.1294 \\
H12 & 0.1915 & -0.0687 & 0.2630 & 0.2538 & -0.7680 \\
Expl.Var & 2.2517 & 2.1664 & 1.7763 & 1.6897 & 1.2872 \\
Prp.Totl & $\mathbf{0 . 1 8 7 6}$ & $\mathbf{0 . 1 8 0 5}$ & $\mathbf{0 . 1 4 8 0}$ & $\mathbf{0 . 1 4 0 8}$ & $\mathbf{0 . 1 0 7 3}$ \\
\hline
\end{tabular}

Source: (Own)

Standardized linear combinations (SLC) derived from the analysis show the following expressions: Factor 1) we have $0.4144(\mathrm{H} 2)+(-0.2988(\mathrm{H} 10)) \ldots+0.1915(\mathrm{H} 12)$ with their own value of 2.2517 that explains $18.76 \%$ of the variance and are two variables who share the factorial weight $\mathrm{H} 3$ and $\mathrm{H} 1$ : Factor 2) $0.0102(\mathrm{H} 2)+0.4575(\mathrm{H} 10) \ldots+(-0.0687(\mathrm{H} 12))$ with their own value of 2.1664 that explains $18.05 \%$ of the variance and are two variables that share the weight informational 
$\mathrm{H} 4$, H5. Factor 3) $0.2327(\mathrm{H} 2)+0.2284(\mathrm{H} 10) \ldots+0.2630(\mathrm{H} 12)$ with their own value of 1.7763 that explains $14.80 \%$ of the variance and are two variables that share the weight informational H6, H8. Factor 4) $0.2455(\mathrm{H} 2)+0.4457(\mathrm{H} 10) \ldots+$ $0.2538(\mathrm{H} 12)$ with their own value of 1.6897 that explains $14.08 \%$ of the variance and the variable which shares the weight informational is $\mathrm{H} 7$.

Finally we have the Factor 5) $0.6860(\mathrm{H} 2)+0.3209(\mathrm{H} 10) \ldots+(-0.7680(\mathrm{H} 12))$ with their own value of 1.2872 that explains $10.73 \%$ of the variance and the variable which shares the weight informational is $\mathrm{H} 12$.

Now, the summary of the five components and the explained variance from its eigenvalues are shown in Table 7:

Table 7. Percentages of explained variance

\begin{tabular}{ccccc}
\hline & \multicolumn{4}{c}{ Extraction: Principal components } \\
Components & Eigenval & \% total Variance & Cumul. Eigenval & Cumul. \% \\
\hline 1 & 2.66415154 & 22.2012629 & 2.66415154 & 22.2012629 \\
2 & 2.30247723 & 19.1873102 & 4.96662877 & 41.3885731 \\
3 & 1.70150557 & 14.1792131 & 6.66813434 & 55.5677862 \\
4 & 1.31771879 & 10.9809899 & 7.98585313 & 66.5487761 \\
5 & 1.18549777 & 9.87914812 & 9.1713509 & 76.4279242 \\
\hline
\end{tabular}

Source: (Own)

The graphical representation of eigenvalues is:

Graphic 1. Eigenvalues

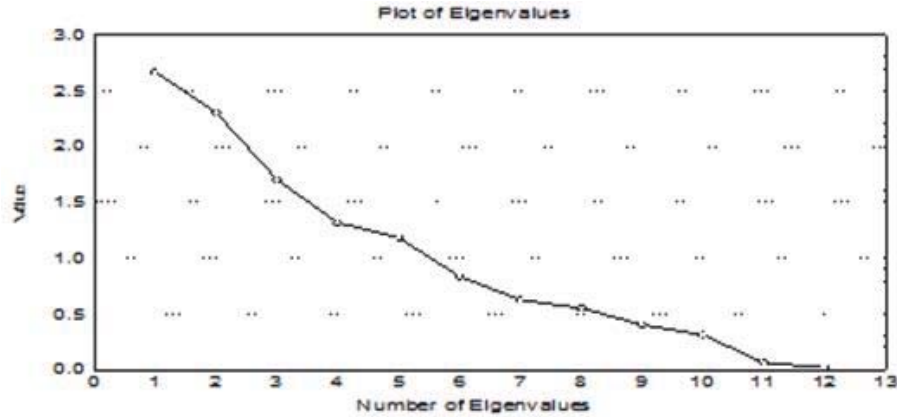

Source: (Own)

With the results shown, we can see the five obtained factors that explain $76.42 \%$ of the variance of the phenomenon under study. In addition to this, it is important to note the complexity of the model that is followed to identify those variables which in the opinion of the executives surveyed, affecting the development of the manufacturing sector under study, hence the conclusions in this empirical study, should be taken with caution

\section{Conclusions}

According with the results, we may say that, the variables which most affect the development of the economic units are: 1) Methods and Techniques 2) Focus on Quality 3) Level of Formal Education and Informal 4) Staff Training and 5) definition and operation of Public Policy. This is consistent with studies by Cheng and Musaphir (1996), Amoako and Boye (1998), Hofsted (1980), Drucker (1996), Hernandez (2007), Hair, et al (2000), Aragon \& Sanchez (2002) who also identified the importance of methods and techniques for the successful development of companies.

In terms of quality, the result is consistent with studies by Philips, Roquebert and Westfall (1993) who determined that the Product Quality affects the market position positively, other authors who refer the importance of focusing on good quality development and business success are: Aragón \& Sánchez (2002), Luck (1996), Camelo (1999) and Donrrosoro, et al. (2001).

About the level instruction "human capital", Metzger (2006) notes that mainly companies with higher "human 
capital" are those with development, which is also consistent with the results of this research.

The results of this study also coincide with studies conducted by Kantis (2004) and Brown (2007) who noted the importance of training, ratings and investment in training workers as factors for companies to succeed. Other studies conducted by Aragon \& Blonde (2005) report some indicators to measure the competitive success of firms, which are: Management skills of the members of an organization and refers to other authors who so determined also Dollinguer (1984); Norburn \& Birley (1988); Huck and McEwen (1991); Viedman (1992); Acar (1993); Yusuf, Boyd and Williams (1995); Ahiere, Golhar and Waller (1996); Luck (1996); Puig (1996); Nightgown (1999); Lin (1998); European Foundation for Quality Management (2000); Ottewill, Jennins and Magir (2000); and Donrrosoro, et al (2001).

In the scope of the definition and operation of public policy, these results are consistent with studies conducted by De Nardi and Phil (2007) who describes the importance of public policies on the stability of the markets, as an option to support the development of the EUs. In this sense Alvarez (2002) and Nase-Gospodarstvo (2008) also refer to the importance of Public Policy as a factor in the successful development of the EUs.

Making a comparison between the main factors studied as variables affecting the development of EUs for 3 countries: Spain, Taiwan and Mexico, we have the following comparisons:

Factors Considered in the Mexican Researches, various Authors as Aragón \& Rubio (2005), Ballina (2010), Velasco (2007), Dutrénit et al. (2010) and Dussel (1990):

1. Health and Safety,

2. Competitiveness / Productivity

3. Formal Instruction /Compensation / Training

4. Public Policy / Market Strategies

5. Quality

6. Technology

7. Company / Characteristics

8. Methods and Techniques

Factors Considered in the Spain Researches (Marbella, 1998):

1. Productivity / Performance / Competitiveness

2. External economic factors / Internationalization

3. Total Quality

4. Innovation R \& D / Design

5. Size / Growth /corporate Culture

6. Leadership Styles

Factors Considered in the Taiwan Researches (Lin, 1998):

1. Human / Resource Capacity

2. External economic factors / Internationalization

3. Quality

4. Innovation $R$ \& D / Design

5. Size / Growth / Corporate Culture

6. Leadership Styles

As can be seen from the lists, according to the literature, six factors are inconsistencies in the 3 countries, and attract attention to the safety aspects and sustainability is not considered as variables studied in some research. As these factors, attention on safety and sustainability, some of the major issues being debated in society today internationally, as situations that impact the economic development of nations.

As shown in the above lists, in investigations in Mexico factors are less considered in studies are as well also the aspects of safety and sustainability. When in Mexico these factors, attention to safety and sustainability, are also some of the main issues being debated today in society, such situations impacting on national and international economic development.

\section{About the Specific Study Questions}

1. What are the factors that impact on the development of economic units in Mexico in the Manufacturing sector? Taking benchmark results we conclude that the variables that most affect the development of the economic units are: V1, V3, V4, V5, V7 and V8.

And they showed less evidence of impact the following variables are: V2, V6, V9, V10, V11, V12. 
2. Which is the order that should address the factors that impact the development of affordable units? Considering the results obtained, the order in which they were treated would be desirable is as follows:

According to the evidence "Z", the attention order would be:

Table 10. Order of attention of factors

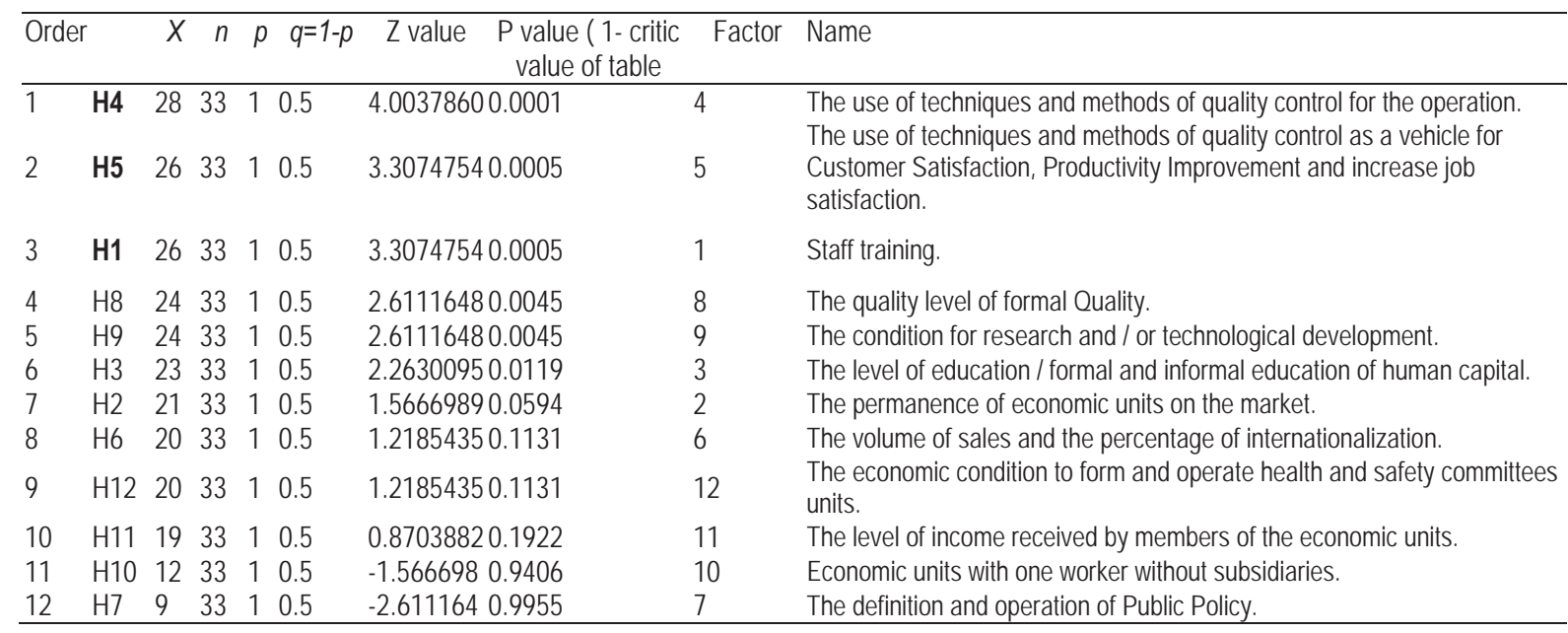

Source: (Own)

According to results showed the factor analysis, the attention order would be:

Table 11. Order of attention of the factors

\begin{tabular}{|c|c|c|c|c|c|c|c|c|}
\hline & & From 1 & From 2 & From 3 & From 4 & From 5 & Multiple & \\
\hline Order & Variable & Factor & Factors & Factors & Factors & Factors & R-Square & Factor Name. \\
\hline 1 & H5 & 0.02077 & 0.85345 & 0.89248 & 0.8933 & 0.93186 & 0.95073 & $\begin{array}{l}\text { The use of techniques and methods of quality control as a } \\
\text { medium for Customer Satisfaction, Productivity } \\
\text { Improvement and increase job satisfaction. }\end{array}$ \\
\hline 2 & $\mathrm{H} 4$ & 0.02715 & 0.83547 & 0.84105 & 0.8542 & 0.92988 & 0.94861 & $\begin{array}{l}\text { The use of techniques and methods of quality control for } \\
\text { the operation. }\end{array}$ \\
\hline 3 & $\mathrm{H} 3$ & 0.75468 & 0.75559 & 0.78557 & 0.78557 & 0.78696 & 0.87884 & The level of formal and Informal Education. \\
\hline 4 & $\mathrm{H} 1$ & 0.69114 & 0.69115 & 0.73973 & 0.80822 & 0.81554 & 0.79305 & Staff training. \\
\hline 5 & H7_1 & 0.44301 & 0.4502 & 0.46099 & 0.82307 & 0.84396 & 0.76978 & The definition and operation of Public Policy. \\
\hline 6 & $\mathrm{H} 8$ & 0.00776 & 0.14843 & 0.68159 & 0.68479 & 0.75238 & 0.68517 & The quality level of formal Quality. \\
\hline 7 & $\mathrm{H} 10$ & 0.01861 & 0.15685 & 0.47449 & 0.64306 & 0.65229 & 0.67342 & Economic units with one worker without subsidiaries. \\
\hline 8 & H6 & 0.12606 & 0.36762 & 0.58189 & 0.65369 & 0.65441 & 0.66847 & $\begin{array}{l}\text { The volume of sales and the percentage of } \\
\text { internationalization. }\end{array}$ \\
\hline 9 & $\mathrm{H} 2$ & 0.35891 & 0.3606 & 0.4163 & 0.41927 & 0.75681 & 0.52346 & The permanence of economic units on the market. \\
\hline 10 & H11 & 0.14349 & 0.14899 & 0.31211 & 0.52183 & 0.56142 & 0.36815 & $\begin{array}{l}\text { The level of income received by members of the } \\
\text { economic units. }\end{array}$ \\
\hline 11 & H9 & 0.01348 & 0.02497 & 0.30743 & 0.721 & 0.72105 & 0.31027 & $\begin{array}{l}\text { The condition for research and / or technological } \\
\text { development. }\end{array}$ \\
\hline 12 & $\mathrm{H} 12$ & 0.0591 & 0.1733 & 0.17451 & 0.17785 & 0.76479 & 0.25539 & $\begin{array}{l}\text { The condition of the economic units to form and operate } \\
\text { health and safety committees. }\end{array}$ \\
\hline
\end{tabular}

Source: (Own)

3. What are the variables and indicators that must be known in order to generate improved productivity of economic units? The results for each of the eight dimensions of the questionnaire used for the collection of information are: 
Table 12. Comparative for each dimension

\begin{tabular}{lcccccccc}
\multicolumn{10}{c}{ (Highest score for each question) } \\
\hline Dimension & SA & AVA & RVA & NEUTRAL & RVD & AVD & SD & $\Sigma$ \\
\hline 2 Organization Style & 0.81 & 0.11 & 0.04 & 0.04 & & & & 1.00 \\
7 Training & 0.78 & 0.19 & 0.03 & & & & & 1.00 \\
4 Quality control, and technology & 0.76 & 0.11 & 0.09 & 0.02 & & 0.02 & & 1.00 \\
5 Jobs Styles & 0.70 & 0.19 & 0.07 & 0.04 & & & & 1.00 \\
8 Security and Cleaning & 0.63 & 0.22 & & 0.07 & & 0.04 & 0 & 1.00 \\
6 Salaries. & 0.59 & 0.26 & 0.07 & 0.08 & & & & 1.00 \\
1 Characteristics of the economic unit & 0.48 & 0.28 & 0.09 & 0.04 & 0.04 & 0.02 & 0.1 & 1.00 \\
3 Marketing Strategies. & 0.46 & 0.28 & 0.17 & 0.06 & 0.03 & & & 1.00 \\
\hline
\end{tabular}

Source: Own

And graphically the results are:

Graphic 2. Dimensions that most affect in Development of economic units

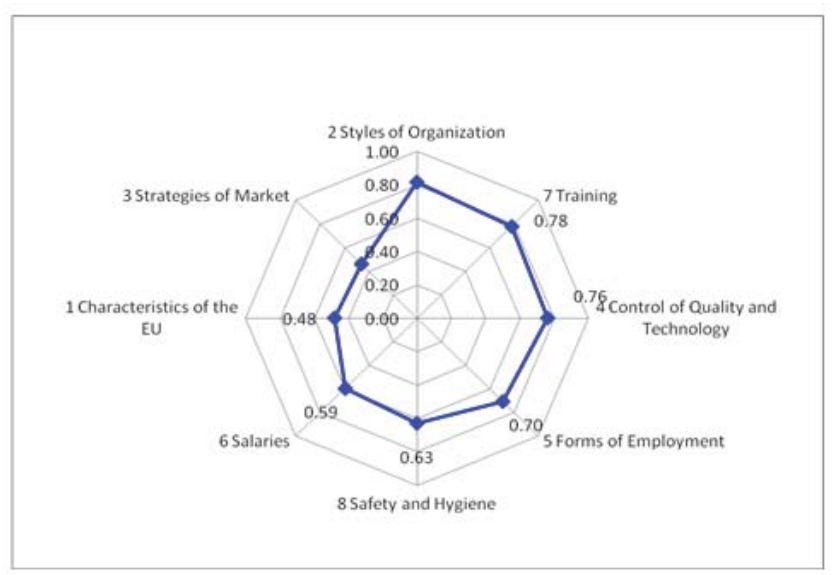

Source: (Own)

The previous information shows graphically that the 3 main dimensions or variables to be cared for in the companies to achieve better development in economic units, are: 1) Organizing Styles 2) Training and 3) Quality Control and Technology. And the 3 dimensions or variable according to respondents may be the most neglected considering that the least impact on their business development are: 1) Market Strategies 2) Characteristics of the Economic Unitsand 3) The Remuneration.

With the previous can be define an alternative model of care to economic units.

4. How should be treated the variables and indicators that impact on the development of economic units, in order to achieve better economic development of these units? From the results the following dimensions / variables to meet are the following:

1) Organizing Styles

2) Forms of Employment

3) Training

4) Market Strategies

5) Quality Control and Technology

6) Characteristics of Economic Units

7) Compensation

8) Safety and Hygiene

5. Which would be an alternative attention model model of economic units in the manufacturing sector, to support more effectively reviving and capitalization of the sector, and also contributes to national economic 
development? As a result of the collection of information and statistics tests, the following alternative model to support the care of the economic sector analyzed units arises:

Figure 2. Alternative model of support for the Development of the EUs

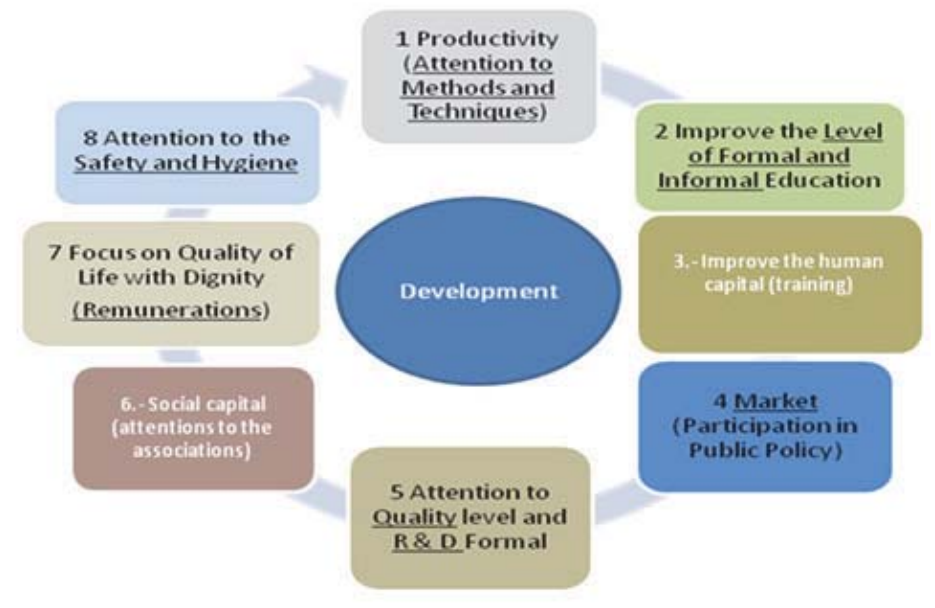

Source: (Own)

\section{Findings}

Related to the theory: During the collection of information, it seems that not all reporting managers know enough different administrative tools that could support improvement in organizational development.

Related to Practice: In the stage of literature review it was identified that the average earnings per employee in the Manufacturing sector in Mexico, which is $\$ 5328.00$ dollars per month. An amount that can be considered as very low, considering the income necessary for a family to demand a dignified quality of life. Salaries range from $\$ 54,030.00$ on average for the Governing Major economic units up to $\$ 1758.00$ on average for General Laborers Micro economic units, i.e., a general worker an EU Micro earns on average 3\% of the gain in directing an average EU Grande. As the following considerations arise: With $\$ 1758.00$ pesos per month will be enough to have a decent quality of life in Mexico? The government and economic units are supporting the human capital in this sector, as for decent wages? Possible economic competitiveness of this sector will be depending on workers' salaries? It is noteworthy that the General Workers in this sector are $1,386,896$ workers and their wages range from $\$ 1758.00$ to $\$ 4.927 .00$ pesos per month on average. When the "PND" (2006) has the following purposes: 1. To achieve sustained rapid growth and generate jobs training them to improve the quality of life for all Mexicans 2. Improve the living conditions and opportunities for all, especially those living in poverty. And this is a social imperative.

From the two previous points the following considerations arise:

1) Lack of knowledge of management of economic units of administrative and economic tools that could support its development, it would be possible to move towards the development of the economic sector in the study?

2) With the average earnings levels taken into Mexico, could it revive businesses and the National Economy?

\section{Recommendations}

1) From the collection of information, $78.8 \%$ of companies do not know the Support Plans and Programs offered by the Public and / or Private Training Responsible, able to design a plan to get companies in Mexico know that Institutions can turn to win support for training.

2) Content of Training Courses can understand the issues in this investigation have been reported and have opportunity for improvement, taking different factors:

- Organization Styles that support better development organizations.

- Promote programs to improve levels of Formal Instruction in companies (Forms of Employment).

- Raise awareness of the importance of investment in training. 
- Educate on the importance on involvement in design, establishment and adjustment of public policies that may impact the development of the EUs in each sector (Market Strategies).

- Develop and support the benefits of Quality Control and Technology.

- Show trends Organizations to count as development support to the Associations and the opportunities that have market penetration by having subsidiaries and develop the culture of the different forms of association (Characteristics of EUs).

- Develop policies that help workers to have enough income to achieve a decent quality of life (Remuneration).

- To emphasize the importance and benefits of Health and Safety.

\section{Future Research Outlines}

The research makes contributions to administrative and economic sciences in terms of the main factors that influence the development of economic units in the study, according to the statistical tests are used during the investigation.

For future research the following are proposed:

1) Know the opinions of executives analyzed with respect to the results of such research sector as well as the views of the cluster in this sector and government institutions such as the Ministry of Economy and the Ministry of Economic Development. Clusters as "FOMAUTO", Mexico: Automotive Works, AC, "CLUSTRANS", Mexico: Cluster AC Motor Carrier Aguascalientes, and Industrial Cameras and "CANACINTRA", Mexico: National Chamber of Industry and Transformation), and the Secretariat of Labor and Social Welfare ("STPS") and the National Institute of Statistics, Geography and Informatics ("INEGI").

2) Extend the study to other EUs and economic sectors of the national economy.

3) Make comparison of results between different sectors of the national economy. And with information from different areas and types of economic units.

4) Know the real interest rate and the development plans of the Ministry of Economic Development, Ministry of Economy, Cluster sector ("FOMAUTO", Mexico: Automotive Works, AC, "ClUSTRANS", Mexico: Aguascalientes cluster Motor Carrier AC), Industrial Chambers ("CANACINTRA", Mexico: Camera National Industry and Transformation), Secretariat of Labor and Social Welfare ("STPS") and the National Institute of Statistics, Geography and Informatics ("INEGI"), on the Manufacturing Sector in Mexico and the Automotive Industry.

5) Analyse the actual role of the agencies described above to support the development of the sector under study.

6) Determine the capacity of local and national government departments to design and operate development plans of the analyzed sector.

7) Compare the vulnerability of economic units of industry against market conditions.

8) Determine how to design and operate the development plans of to the government officials in that sector.

9) Continue to improve the model of care to the economic sector units based on the studies.

\section{References}

Acar A. (1993). The impact of Key International Factor on Firm Performance: an Empirical Study of Small Turkish Firms. The Journals of Small Business Management, vol. 31, no. 4, pp. 86-92.

Ahiere S.L., Golhar D.Y y Waller M.A. (1996). Development and Validation of TQM Implementation Constructs. Decisions Sciences, vol. 27. no. 1, winter, pp. 23-56.

Aimar M. J. (2011). Investigacion de Mercado II. Universidad de Ciencias Empresariales y Sociales. Sede Rafaela.

Amoako K. y Boye S. (1998). Operations strategy in an emerging economy: the case of the Ghanaian manufacturing industry. Journal of Operations Management, n.19, pp. 59-79.

Anderson, D., Sweeney, D.J. y Williams, T.A. (2008). Estadística para administración y economía. 10a. edición, University of Cincinnati. USA. Cengage Learning Editores, S.A. de C.V.

Aragón A. y Sánchez G. (2002). Orientación estratégica, características de gestión y resultados: Un estudio de la PYME españolas. Universidad de Murcia, Facultad de Economía y Empresa, Departamento de Organización de Empresas, versión de noviembre, ICE, Tribuna de Economía. España.

Aragón A. \& Rubio A. (2005). Factores explicativos de éxito competitivo: El caso de las PyMES del estado de Veracruz. Universidad Nacional Autónoma de México Contaduría y Administración, mayo -agosto, número 216, Distrito Federal, México, pp. 35-69.

Augusto, C. (2006). Metodología de la Investigación. Segunda edición, Facultad de Ciencias Económico Administrativas, Universidad de la Sabana. Colombia. Pearson Prentice Hall. 
Ballina F. (2010). Análisis Estratégico para el Desarrollo de la MPYME del Distrito Federal: Informe Ejecutivo 2010. Observatorio para las micro, pequeñas y medianas empresas, D.F.

Baró, J. y Alemany, R. (2000). Estadística II. Ed. Fundación per a la Universidad Oberta de Catalunya. Barcelona. España.

Brown S. (2007). Seven Skills for the Aspiring Entrepreneur. Business \& Economic Review, Vol. 53 Issue 2, p16-18, 3p; (AN 23736176).

Camelo C. (1999). El estudio de la estrategia de diversificación desde la teoría basada en el conocimiento. Revista Europea de Dirección y Economía de la Empresa, vol. 8, no. 4, pp. 33-54.

Cheng T. y Musaphir H. (1996). Theory and Practice of Manufacturing Strategy. International Journal of Production Research, v34, pp 1243-1259.

Clasificación Mexicana de Actividades y Productos (1994). CMAP. [Online] Available: http://inegi.org.mex (April 11, 2011)

Cole E. y Scott R. (2000). The Quality Movement and Organization Theory. Sage Publications, Thousand Oaks (CA).

Córdova, A. (2011). Perfil del sector manufacturero en México (factores que más inciden en su desarrollo de las unidades económicas. Tesis Doctoral. Universidad Autónoma de Zacatecas, Zacatecas, Zac., México.

Datos 3 (2011), Tratamiento Estadístico. Estudio de Mercado: El Análisis Factorial de Componentes Principales vs El Análisis de Correspondencias. [Online] Available: http://3datos.es/wp-content/uploads/2011/04/AF-de-CP-vs-AC.pdf (April 11, 2011)

Dollinguer J. (1984). Environmental boundary spanning and information processing effects on organizational performance. Academy of Management Journal, Vol. 27, no. 2, pp. 351-368.

Donrrosoro I, García C., González M., Lezámiz M., Matery J. Moso M., Unzuela M. (2001). El Modelo de gestión de las PYMEs vascas de éxito. Edita Clúster del Conocimiento (Portal de Gestión) y ediciones PMP. Bilbao.

Drucker P. (1996). Su visión sobre: La administración, la organización basada en la información, la economía, la sociedad (318p.) Santafé de Bogotá Colombia, Norma.

Dussel E. (1990). El último Marx (1863-1882) y la liberación latinoamericana. Siglo XXI, México, ISBN 968-23-1649-9.

Dutrénit G., Capdevielle M., Corona Juan. M., Puchet M., Vera-Cruz F. S. y Alexandre O. (2010). El Sistema Nacional de Innovación Mexicano: Instituciones, Políticas, Desempeño y Desafíos. Universidad Autónoma Metropolitana, Edición Monocromo.

Encuesta Nacional de Empleo, Salarios, Tecnología y Capacitación en el Sector Manufacturero "ENESTYC" (2005). STPS e INEGI. [Online] Available: http://www.inegi.org.mx/prod_serv/contenidos/espanol/bvinegi/productos/estudios/sociodemografico/enestycl 2005/ENESTYC_2005.pdf (April 11, 2011).

European Foundation for Quality Management (2000). [Online] Available: http://efqm.org (April 11, 2011)

García A. (2004). Estudio empírico sobre Alianza para el Campo, Procampo, remesas y financiamiento bancario y su influencia en el saneamiento de las finanzas rurales y la producción agropecuaria. El caso de Aguascalientes (Factibilidad para Bursatilizar Procampo). Tesis Doctoral. UQ, UAA, UC, UAQZ, UASLP, UJED, UNAM, ISBN: 84-688-8062-0 Disponible en: http://eumed.net /tesis/ags/index.htm

Gómez, F. (1988). Análisis factorial por componentes principales (Algunos aspectos interesantes). Estadística Española, Vol. 30, Núm. 1 18. Facultad de Ciencias Económicas y Empresariales Universidad de Deusto-Bilbao, Apartado 20044 - 48080 Bilbao págs. 215 a 232.

Guzmán, M. (1991). Curso básico de estadística económica. AC, DL. Madrid, España. ISBN: 84-7288-142-3

Grant R., Shani R. y Krishnan R. (1994). TQM's Challenge to Management Theory and Practice. Sloan Management Review, vol. 43, no. 2, pp.25-35.

Hofsted G. (1980). Motivation, leadership and organization Do American theories applied abroad. Organizational Dynamics 9: 42-63.

Huck J. y McEwen T. (1991). Competencies needed for small business success: Perceptions of Jamaican entrepreneurs. Journal of Small Business Management, October, vol. 29, n. ${ }^{0} 2$, pp. 90-93.

Johnson, R. R. (1996). Elementary statistics. Belmont. Duxbury, Cop.

Kantis, H. (2004). Desarrollo Emprendedor: América Latina y la experiencia internacional. Ashgate publishing Kantis, Colombia. Banco Interamericano de Desarrollo, Editorial Nomos.

INEGI (2010). Banco de Información Económica. [Online] Available: http://dgcnesyp.inegi.gob.mx/ (April 11, 2011).

INEGI (2001). Encuesta Nacional de Empleo, Salarios, Tecnología y Capacitación en el Sector Manufacturero (ENESTYC). STyPS e INEGI.

Lee T.S., Adam E., y Tuan C. (1999). The Convergent and Predictive Validity of Quality and Productivity Practices in Hong Kong Industry. Total Quality Management, vol. 10, no. 1, pp.73-84.

Lin C. (1998). Success factors of small -and medium- sized enterprise in Taiwan: An analysis of cases. Journal of Small Business Management, October, Vol. 36, n. 4, p. 43-56.

Luck, S. (1996). Success in Hong Kong: Factors self-reported by successful small business owners. Journal of Small Business Management, October, Vol. 34, n. 3, p. 68-75.

Marbella F. (1998). Competitividad de las empresas Castellano-Leonesas: Análisis de algunos factores relevantes. Sexto Congreso de Economía Regional de Castilla y León, Zamora.

Metzger G. (2006). The Performance of Entrepreneurial Restarts. KfW Bankengruppe; Center for European Economic Research (ZEW) - Industrial Economics and International Management Research, Discussion Paper No. 06-083.

Nase-Gospodarstvo (2008). The role of foreign direct investment in raising national competitiveness. Our Economy, Vol. 54 Issue 1/2, p120-128, 9p; (AN 31208416).

Nieto, A. , Extremera, S. y Gómez, J. (2011). Bayesian hypothesis testing for proportions. Paper SP08, PhUSE, Madrid, Spain.

Norburn D. and Birley S. (1988). The Top Management team and corporate performance. Strategic Management Review, Winter, pp 
127-137.

OECD (2009). Economic, Environmental and Social Statistics. Factbook - ISBN 92-64-05604-1 - @ OECD 2009.

OECD (2011). Organización para la Cooperación y el Desarrollo Económico. [Online] Available: http://www.ocde.org (April 11, 2011).

Ottewill P., Jennins P. y Magir P. (2000). Management competence development for professional service SMEs: The case of community pharmacy. Education \& Training, Vol. 42, N 4/5, pp. 246-254.

Peña, D. (1987). Estadística. Modelos y Métodos. Volumen 2. Alianza Editorial. Madrid, España. ISBN: 84-206-8110-5

Philips R., Roquebert J. y Westfall P. (1993). Markets vs. Management: what drives profitability?. Strategic Management Journal, vol. 17, pp. 653-664.

Plan Nacional de Desarrollo 2007-2012 (2006) "PNP". [Online] Available: http://pnd.presidencia.gob.mx/ (January, 2011).

Powell T.C. (1995). Total Quality Management as Competitive Advantage: a Review and Empirical Study. Strategic Management Journal, vol. 16, pp. 15-37.

Puig P. (1996). La competitivita de l'empresa industrial a Catalunya. Anàlisis de l'entorn econòmic i de las estratègies competitives en un contexte de modernització del sector públic. ESADE, Barcelona.

Reed R., Lemark D.J. y Montgomery J.C. (1996). Beyond Process: TQM Content and Firma Performance. Academy of Management Review, vol. 21, no. 1, pp. 173-201.

Secretaría del Trabajo y Previsión Social (2011) "STPS". [Online] Available: http://stps.gob.mx (April 11, 2011).

Tena J. y Comai A. (2004). La Inteligencia Competitiva en las Mejores Prácticas Españolas. EMECOM en colaboración con PUZZLE Revista Hispana de la Inteligencia Competitiva, ISBN-10 84-609-3686-4.

Terziovski M. y Samson D. (1999). The Link Between Total Quality Management Practice and Organizational Performance. International Journal of Quality \& Reliability Management, vol. 16, no. 3, pp. 226, 237.

Velasco G. (2007). Factores explicativos del éxito empresarial: El caso de las Micro, Pequeñas y Medianas Empresas (MIPYME) del Estado de Chihuahua. CSA - UACJ, Desarrollo Regional y Competitividad Empresarial.

Viedman J.M. (1992). La Excelencia Empresarial. México: McGraw Hill de Management.

Yusuf M.A., Boyd J. y Williams E. (1995). The Impact of the Quality Management on Firms' Responsiveness: an Empirical Analysis. Total Quality Management, vol. 7, no. 1, pp. 127-144. 